Baseline

\title{
Exposure to crack cocaine causes adverse effects on marine mussels Perna perna
}

\author{
L.A. Maranho ${ }^{a}$, M.K. Fontes ${ }^{\mathrm{a}}$, A.S.S. Kamimura ${ }^{\mathrm{b}}$, C.R. Nobre ${ }^{\mathrm{b}}$, B.B. Moreno ${ }^{\mathrm{a}}$, F.H. Pusceddu ${ }^{\mathrm{b}}$, \\ F.S. Cortez ${ }^{\mathrm{b}}$, D.T. Lebre ${ }^{\mathrm{c}}$, J.R. Marques ${ }^{\mathrm{c}}$, D.M.S. Abessa ${ }^{\mathrm{d}}$, D.A. Ribeiro ${ }^{\mathrm{e}}$, C.D.S. Pereira ${ }^{\mathrm{a}, \mathrm{b}, *}$ \\ a Departamento de Ciências do Mar, Universidade Federal de São Paulo, Rua Dr. Carvalho de Mendonça, 144, 11070-102 Santos, Brazil \\ b Laboratório de Ecotoxicologia, Universidade Santa Cecília, Rua Oswaldo Cruz 266, 11045-907 Santos, Brazil \\ c CEMSA - Centro de Espectrometria de Massas Aplicada, CIETEC/IPEN, Av. Prof. Lineu Prestes, 2242, Salas 112 e 113, 05508-000 São Paulo, Brazil \\ d Instituto de Biociências, Campus do Litoral Paulista, Universidade Estadual Paulista “Júlio de Mesquita Filho", Infante Dom Henrique, s/n, 11330-900 São Vicente, \\ Brazil \\ e Departamento de Biociências, Universidade Federal de São Paulo, Av. Ana Costa 95, 11060-001 Santos, Brazil
}

\section{A R T I C L E I N F O}

\section{Keywords:}

Crack cocaine

Bioassays

Cyto-genotoxicity

Marine organism

\begin{abstract}
A B S T R A C T
Our study aimed to evaluate crack cocaine effects in different life stages of the marine mussel Perna perna. For this purpose, fertilization rate, embryo-larval development, lysosomal membrane stability and DNA strand breaks were assessed. Effect concentrations in gametes and in larval development were found after $1 \mathrm{~h}$ $\left(\mathrm{IC}_{50}=23.53 \mathrm{mg} \cdot \mathrm{L}^{-1}\right)$ and $48 \mathrm{~h}\left(\mathrm{IC}_{50}=16.31 \mathrm{mg} \cdot \mathrm{L}^{-1}\right)$, respectively. The highest tested concentration showing no acute toxicity (NOEC) was $10 \mathrm{mg} \cdot \mathrm{L}^{-1}$, while the lowest observed effect concentration (LOEC) was $20 \mathrm{mg} \cdot \mathrm{L}^{-1}$. NOEC concerning embryo-larval development was $0.625 \mathrm{mg} \cdot \mathrm{L}^{-1}$, while the LOEC was $1.25 \mathrm{mg} \cdot \mathrm{L}^{-1}$. Cyto-genotoxic effects were evidenced in mussels exposed to crack cocaine concentrations ranging from 5 to $500 \mu \mathrm{g} \cdot \mathrm{L}^{-1}$. Our results report the first data on effects of an illicit drug to marine organisms and should encourage further ecotoxicological studies of these contaminants of emerging concern in coastal ecosystems.
\end{abstract}

Illicit drugs are a growing public health problem worldwide which cocaine and marijuana are the most consumed ones. The World Drug Report (UNODC, 2014) observed that the highest consumption of cocaine (including crack cocaine) occurs in the Americas. In North America, cocaine consumption has declined since 2006, partly due to a sustained shortage, although they are considered the largest consumers in the world. Illicit drug use has increased dramatically in the last decade in developing countries of South America (Johnson et al., 2013). The consumption and trafficking of cocaine in South America have become more prominent, particularly in Brazil, due to factors such as geographic location and the population increase clustered in urban centers. Brazilian cocaine users were estimated to be nearly 2 million in the 2004-2005 period, and this number rose to 3.35 million in 2012 (UNODC, 2014). Brazil has been reported as the world's largest market for crack cocaine (Laranjeira et al., 2012) and the main cocaine destination country in South America over the period 2010-2015 (UNODC, 2017).

The increase in illicit drugs consumption produces not only public health problems, but also induces potential environmental impacts since these contaminants of emerging concern were recently identified as toxic for aquatic organisms (Binelli et al., 2012; Parolini et al., 2013).

Such compounds are continually released into the environment via wastewater treatment plants (WWTPs). Concerning freshwater environments, many studies have been published about real concentrations of cocaine in surface waters (Hernández et al., 2015; Baker and Kasprzyk-Hordern, 2013; Baker et al., 2012; Castiglioni et al., 2011; Metcalfe et al., 2010; Van Nuijs et al., 2009). However, few studies have analyzed estuarine and marine environments. Klosterhaus et al. (2013) found cocaine in seawater $\left(2.4 \mathrm{ng} \cdot \mathrm{L}^{-1}\right)$, sediment $\left(0.2 \mathrm{ng} \cdot \mathrm{g}^{-1} \mathrm{dw}\right)$ and mussels (0.3 ng.g $\left.{ }^{-1} \mathrm{ww}\right)$ from San Francisco Bay (USA). Recently, Pereira et al. (2016) found higher concentrations of cocaine and benzoylecgonine (537.0 ng. $\mathrm{L}^{-1}$ and $20.8 \mathrm{ng} \cdot \mathrm{L}^{-1}$, respectively) in seawater samples from Santos Bay (Brazil).

As pointed out by Binelli et al. (2012), although some researchers have focused on the development of reliable methodologies to quantify illicit drug concentrations in aquatic environments, few data are available on the acute or chronic effects of these compounds on the aquatic community. Cyto-genotoxic effects were detected in the zebra mussel (Dreissena polymorpha) exposed to environmentally relevant concentrations of cocaine (Binelli et al., 2012), benzoylecgonine

\footnotetext{
* Corresponding author at: Departamento de Ciências do Mar, UNIFESP - Campus Baixada Santista, Brazil.

E-mail address: camilo.seabra@unifesp.br (C.D.S. Pereira).
} 
(Parolini et al., 2013), or a realistic mixture of cocaine, benzoylecgonine, amphetamine, morphine and 3,4-methylenedioxymetham-phetamine (Parolini et al., 2015).

The occurrence of cocaine and its main human metabolite, benzoylecgonine, in coastal waters suggests the need for ecotoxicological studies in order to elucidate the mechanism of action and adverse effects of these compounds on marine biota. To the best of our knowledge, no data are available on possible damage produced by illicit drugs or their metabolites on marine organisms.

Among marine organisms, bivalves gained global importance as bioindicators and have been extensively used in biomonitoring programs of coastal waters (Maranho et al., 2015a, 2015b; Pereira et al., 2014; Aguirre-Martínez et al., 2013; Martín-Díaz et al., 2007). These organisms have broad geographical distribution, availability in the field and through aquaculture production, as well as suitability for laboratory and in situ experiments (Maranho et al., 2015c; Cajaraville et al., 2000).

Mussels Perna perna are found in natural deposits of the intertidal areas subjected to direct impact of waves and high hydrodynamics. They are filter feeders of phytoplankton and suspended particulate matter. This bioindicator was previously validated as recommended test organism for environmental quality assessments (Pereira et al., 2012, 2011, 2007; Abessa et al., 2005).

Crack cocaine is a very toxic by-product of cocaine, resulting from the addition of sodium bicarbonate to cocaine base paste (Falck et al., 2008). The most recent Brazilian national population-based survey was conducted in 2012 and revealed that two million Brazilians were using crack cocaine (Laranjeira et al., 2012). These data show that its consumption in Brazil is continuing to increase and might be considered as "epidemic", mainly in metropolitan regions (Oliveira et al., 2014). This compound is able to induce genotoxicity in peripheral blood, liver and brain cells of mice (Yujra et al., 2016), as well as genomic damage in multiple organs of Wistar rats (Moretti et al., 2016).

In light of the high consumption of crack cocaine in the metropolitan coastal region of Santos (São Paulo, Brazil), the occurrence in seawater, and the potential toxicity for aquatic organisms, our study aimed to assess fertilization rate, embryotoxicity and cyto-genotoxicity of crack cocaine in different life stages of the marine mussel Perna perna.

An aliquot of crack cocaine $(100 \mathrm{mg})$, as well as the highest concentration of the biomarker's assay $\left(500 \mu \mathrm{g} \cdot \mathrm{L}^{-1}\right)$ were analyzed by LCMS/MS to quantify cocaine. Samples were analyzed by an HPLC Agilent 1260 (Agilent Technologies, CA, USA) combined with a 3200 QTRAP hybrid triple quadrupole/LIT (linear ion trap) mass spectrometer Sciex, Ontario (Canada), according procedure described by Shihomatsu (2015) and employed by Pereira et al. (2016). The cocaine standard used was bought from Cerilliant (FE07271503).

The conditions used for the LC separation were as follows: An injection volume of $10 \mu \mathrm{L}$ of each sample was analyzed by an Agilent Eclipse XDB-C18 $4.6 \times 50 \mathrm{~mm}, 1.8 \mu \mathrm{m}$ column at $25^{\circ} \mathrm{C}$. The eluent flow rate was $0.7 \mathrm{~mL} \cdot \mathrm{min}^{-1}$, and the mobile phase for positive mode analysis was $0.1 \%$ formic acid (Sigma-Aldrich LC-MS Grade) in water (solvent A) and acetonitrile (J.T. Baker LC-MS Grade) (solvent B). A linear gradient of $0.7 \mathrm{~mL} \cdot \mathrm{min}^{-1}$ was used, starting with a mixture of $95 \%$ solvent A and $5 \%$ solvent B. The solvent A percentage decreased linearly from $95 \%$ to $5 \%$ over the course of $5 \mathrm{~min}$ and this condition was maintained for $1 \mathrm{~min}$. The mixture was then returned to the initial condition over the course of $2 \mathrm{~min}$. Cocaine was detected and quantified using ESI ionization and Multiple Reaction Monitoring (MRM) mode, with the selection of a precursor ion and two ion products to quantify and qualify the compound. Data were recorded and processed using Analyst ${ }^{\circledR}$ 1.5.2 (Sciex, Ontario, Canada).

MRM parameters, limit of detection (LOD) and limit of quantification (LOQ) are shown in Table 1.

Adult mussels Perna perna were acquired from a long-line shellfishfarming zone located at the Toque-Toque beach, São Sebastião (São
Table 1

Parameters of multiple reactions monitoring for the positive ion mode, limit of detection, limit of quantification and retention time.

\begin{tabular}{lllllllll}
\hline Compound & Q1 & Q3 & $\begin{array}{l}\text { DP } \\
(\mathrm{V})\end{array}$ & $\begin{array}{l}\text { CE } \\
(\mathrm{V})\end{array}$ & $\begin{array}{l}\mathrm{CXP} \\
(\mathrm{V})\end{array}$ & $\begin{array}{l}\mathrm{LOD} \\
\left(\mathrm{ng} \cdot \mathrm{L}^{-1}\right)\end{array}$ & $\begin{array}{l}\mathrm{LOQ} \\
\left(\mathrm{ng} \cdot \mathrm{L}^{-1}\right)\end{array}$ & $\begin{array}{l}\mathrm{RT} \\
(\mathrm{min})\end{array}$ \\
\hline Cocaine & 304.2 & $\begin{array}{l}182.2 \\
105.1\end{array}$ & 36 & 27 & 4 & 3.0 & 12.0 & 3.90 \\
& & 105 & 39 & & & \\
\hline
\end{tabular}

Q1 (first quadrupole); Q3 (last quadrupole); DP (Declustering potential); CE (Collision Energy); CXP (Collision Exit Potential); LOD (Limits of detection); LOQ (Limits of quantification); RT (Retention Time). In Q3, in the upper cell is the quantifier ion and in the lower cell is the qualifier ion.

Paulo, Brazil). Individuals (average $74.5 \times 36.2 \mathrm{~mm}$ ) were transported to the laboratory where they were kept in a $300 \mathrm{~L}$ aquarium filled with seawater for $24 \mathrm{~h}$ prior to the assays, under controlled temperature $\left(25^{\circ} \mathrm{C}\right)$ and salinity $(35 \mathrm{ppt})$.

Natural seawater employed in the bioassays was obtained in the mussel farm area, previously selected based on the results of the environmental monitoring performed by the São Paulo Environmental Agency, which has detected aquatic contaminants below threshold levels in this area (CETESB, 2016). Seawater was previously filtered through a cellulose membrane of $0.22 \mu \mathrm{m}$ for the acute and chronic assays. For the biomarker assays, natural seawater was filtered $(150 \mu \mathrm{m})$ and maintained under aeration during the assays.

In order to assess the fertilization rate and larvae development, bioassays were performed following the protocol recommended for mussels by ASTM (1992), with minor adaptations proposed by Zaroni et al. (2005). For the fertilization rate $(n=5)$ and the larvae development assays $(n=5)$, adult individuals were induced to spawn by thermal stimulation, and gametes from at least three males and three females were collected separately and transferred to glass beakers. Four replicates were used for concentrations ranged from 0 to $100 \mathrm{mg} \cdot \mathrm{L}^{-1}$, including the solvent control (seawater plus DMSO 1:500 v/v).

The fertilization rate was assessed by adding a solution of sperm (density around $5 \times 10^{7}$ spermatozoa/mL) to glass tubes containing crack cocaine concentrations. After $40 \mathrm{~min}$, oocytes were added to the glass tubes. After $60 \mathrm{~min}$ of exposure, formaldehyde was added to each vial and the first 100 fertilized eggs from each replicate were analyzed with the aid of a Sedgwick-Rafter under an optical microscope. Fertilization was checked for the presence of polar body or start of cleavages.

For the embryo-larval development assay, the fecundation was first attained by adding $2 \mathrm{~mL}$ of sperm solution to $200 \mathrm{~mL}$ of ovules solution. With the aid of a Sedgwick-Rafter chamber, the density of fertilized eggs was estimated and about 500 embryos were transferred to glass tubes containing crack cocaine concentrations for a period of $48 \mathrm{~h}$ at $25{ }^{\circ} \mathrm{C}$ and salinity of $35 \mathrm{ppt}$. Four replicates were used for each group, including solvent control (seawater plus DMSO 1:500 v/v). After the exposure period, formaldehyde was added to each vial and the first 100 larvae from each replicate were analyzed. Larvae developed to D-phase were considered normal, whereas those presenting delay and/or morphological anomalies (irregular shape and extravasation of contents) were considered abnormal (Pereira et al., 2014; Cortez et al., 2012; Zaroni et al., 2005).

The mean percentage of normal fertilization rate and embryo-larval development was calculated for each tested concentration. Through these bioassays were obtained (i) the mean concentration of crack cocaine that causes fertilization rate and embryo-larval development inhibition to $50 \%$ of the exposed organisms ( $\left(\mathrm{IC}_{50} ; 48 \mathrm{~h}\right.$ ); (ii) the highest tested concentrations showing no adverse effects (No Observable Effect Concentration - NOEC); and (iii) the lowest tested concentrations showing significant toxicity (Lowest Observable Effect Concentration LOEC).

Mussels $P$. perna were exposed for $48 \mathrm{~h}$ to four crack cocaine concentrations in a way to evaluate cytotoxicity (lysosomal membrane 
stability - LMS) and genotoxicity (DNA strand breaks). Two aquariums filled with the corresponding dilution were used for each concentration. Crack cocaine concentrations tested were $0.5,5,50$ and $500 \mu \mathrm{g} \cdot \mathrm{L}^{-1}$, based on environmental concentrations of cocaine previously reported by Pereira et al. (2016) in Santos Bay (São Paulo, Brazil).

Due to its low solubility in water, crack cocaine was first dissolved in dimethylsulfoxide (DMSO) before being diluted in seawater to prepare a stock solution. The highest DMSO concentration used in each experiment was simultaneously tested as the solvent control.

Twenty animals were placed in each aquarium under controlled conditions (pH: $7.9 \pm 0.2$; salinity: $35 \pm 2$; temperature: $20 \pm 2{ }^{\circ} \mathrm{C}$; dissolved oxygen: $8.5 \pm 1.4 \mathrm{mg} \cdot \mathrm{L}^{-1}$ ). After $48 \mathrm{~h}$ of exposure, haemolymph was withdrawn to perform Neutral Red Retention Time (NRRT) assay. Subsequently, organisms were dissected and digestive glands were frozen in $-80^{\circ} \mathrm{C}$ freezer for genotoxicity analyses.

NRRT assay is based on the principle that only lysosomes in healthy cells take up and retain the vital dye neutral red. Lysosomal membranes' damage caused by the impact of xenobiotics can decrease the dye retention time by inducing the leaking of lysosomal components (Dailianis et al., 2003). NRRT assay was performed following the nondestructive method described by Lowe et al. (1995). Haemolymph of $P$. perna was withdrawn from the posterior adductor muscle of living bivalves and was mixed with physiological saline solution (pH 7.3 containing $4.77 \mathrm{~g} \cdot \mathrm{L}^{-1}$ HEPES, $25.48 \mathrm{~g} \cdot \mathrm{L}^{-1} \mathrm{NaCl}, 13.06 \mathrm{~g} \cdot \mathrm{L}^{-1} \mathrm{MgSO}_{4}$, $0.75 \mathrm{~g} \cdot \mathrm{L}^{-1} \mathrm{KCl}, 1.47 \mathrm{~g} \cdot \mathrm{L}^{-1} \mathrm{CaCl}_{2}$ ).

This solution was spread on slides and transferred to a lightproof chamber, where it remained $15 \mathrm{~min}$ to allow cells attachment. Excess liquid was removed and $40 \mu \mathrm{L}$ of the Neutral Red (NR) dye were added to the cell monolayer. A cover slip was added. After 15 min incubation period, slides were examined every $15 \mathrm{~min}$ by optical microscopy $(400 \times)$ for both structural abnormalities and NR dye loss from lysosomes to cytosol. The endpoint was considered when dye loss was evident in 50\% (numerically assessed per field of view) of the small granular haemocytes. NRRT mean value was calculated for each crack cocaine concentration.

Digestive glands from individuals ( $n=40$ exposed to each concentration and solvent control) were excised, pooled $(n=3)$ and homogenized (homogenized fraction - HF) in a buffer solution ( $\mathrm{pH} 7.6$ ) containing Tris-HCl $(50 \mathrm{mM})$, EDTA $(1 \mathrm{mM})$, DTT $(1 \mathrm{mM})$, sucrose $(50 \mathrm{mM})$ and $\mathrm{KCl}(150 \mathrm{mM})$. PMSF $(100 \mathrm{mM})$ was added to the daily solution. Total protein content $\left(\mathrm{mg} \cdot \mathrm{mL}^{-1}\right)$ was determined according to Bradford (1976) method, using serum bovine for calibration. All biomarker responses were determined using Biotek Synergy HTX microplate reader and software $\mathrm{Gen} 5^{\mathrm{TM}}$.

HF was used to the determination of DNA damage (strand breaks). DNA damage was assessed by the alkaline precipitation assay (Olive, 1988) based on the K-SDS precipitation of DNA-protein cross links and using fluorescence to quantify the DNA strand breaks (Gagné et al., 1995). HF sample was mixed with $200 \mu \mathrm{l}$ of $2 \%$ SDS containing $10 \mathrm{mM}$ EDTA, $10 \mathrm{mM}$ Tris-base and $40 \mathrm{mM} \mathrm{NaOH}$. After mixing by inversion, the solution was stocked at room temperature for $1 \mathrm{~min}, 200 \mu \mathrm{L}$ of $0.12 \mathrm{M} \mathrm{KCl}$ was added and the solution heated to $60{ }^{\circ} \mathrm{C}$ for $10 \mathrm{~min}$. The solution was incubated at $4{ }^{\circ} \mathrm{C}$ for $30 \mathrm{~min}$ to precipitate the genomic DNA bound to SDS associated with nucleoproteins. This mixture was centrifuged at $8000 \mathrm{~g}$ for $5 \mathrm{~min}$ at $4{ }^{\circ} \mathrm{C}$. Supernatant fraction was added to $150 \mu \mathrm{l}$ of Hoechst dye at a concentration of 100 .

$\mathrm{nM}$ (diluted with $100 \mathrm{mM}$ Tris- $\mathrm{HCl}$, containing $400 \mathrm{mM} \mathrm{NaCl}$ and $4 \mathrm{mM}$ sodium cholate, $\mathrm{pH}$ 8.5) in dark microplates. Salmon sperm DNA standards were used for the calibration curve, with different concentrations (i.e., 0, 0.91, 2.27, 4.55, 9.09, 27.30 and $45.55 \mu \mathrm{g} \cdot \mathrm{mL}^{-1}$ ). Fluorescence readings were taken at $360 \mathrm{~nm}$ (excitation) and $450 \mathrm{~nm}$ (emission). Data were expressed as $\mu \mathrm{g}$ DNA strands/mg protein.

Our hypothesis considered that different life stages of $P$. perna were significantly affected by exposure to concentrations of crack cocaine, which was statistically tested by Analysis of Variance (ANOVA). The data were firstly analyzed for normality using Chi-square goodness of fit

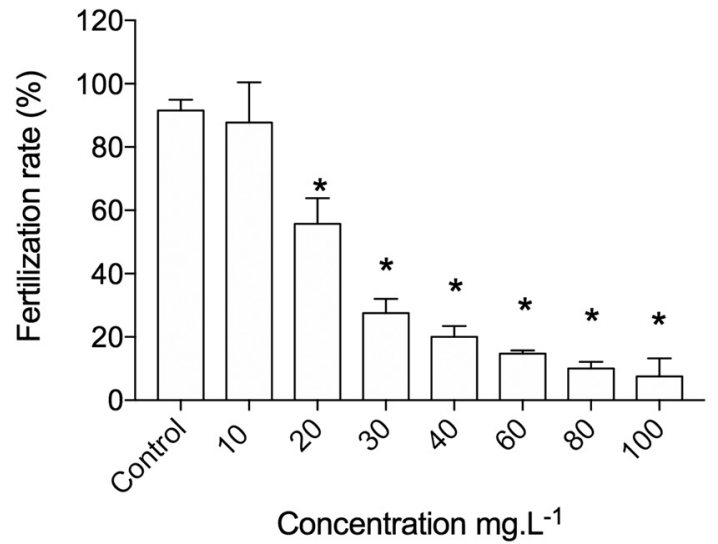

Fig. 1. Fertilization assay. Spermatozoids were exposed for $1 \mathrm{~h}$ to crack cocaine. Asterisks (*) indicate significant differences at $\mathrm{p}<0.05$.

test, and subsequently analyzed for homoscedasticity by the Bartlett's test. Student's $t$-test was employed to identify significant differences between control and the highest concentration of the solvent DMSO in each assay. Since no differences were found, solvent control was employed for all analysis. ANOVA followed by the Dunnett's test were used to identify the concentrations significantly different from control (No Observed Effect Concentration - NOEC and Low Observed Effect Concentration - LOEC) for each assay. Significance level was set at $\mathrm{p}<0.05$. Statistical analysis was performed employing PRISM version 7.0a. The Linear Interpolation method (Norber-King, 1988) was used to calculate the set of $\mathrm{IC}_{50}$ for the fertilization and embryo-larval development assays.

The aliquot of crack cocaine analyzed by LC-MS/MS contained $37.99 \%$ of cocaine. Acute effect in gametes (fertilization assay) occurred after $1 \mathrm{~h}$ exposure $\left(\mathrm{IC}_{50}=23.53 \mathrm{mg} \cdot \mathrm{L}^{-1}\right.$ ), while $\mathrm{IC}_{50}$ on normal embryo-larval development exposed $48 \mathrm{~h}$ to crack cocaine concentration was $16.31 \mathrm{mg} \cdot \mathrm{L}^{-1}$. The highest tested concentration showing no acute toxicity (NOEC) was $10.0 \mathrm{mg} \cdot \mathrm{L}^{-1}$, while the lowest observed effect concentration (LOEC) was $20.0 \mathrm{mg} \cdot \mathrm{L}^{-1}$ (Fig.1). NOEC concerning embryo-larval development was $0.625 \mathrm{mg} \cdot \mathrm{L}^{-1}$, while the LOEC was $1.25 \mathrm{mg} \cdot \mathrm{L}^{-1}$ (Fig. 2).

A summary of effect concentrations on reproductive parameters of Perna perna is shown in Table 2.

Measured concentrations of cocaine for the biomarker assay are showed in Table 3.

Mussels exposed to all concentrations except $0.5 \mu \mathrm{g} \cdot \mathrm{L}^{-1}$ were under significant stress ( $\mathrm{p}<0.05$ ), according to NRRT (Fig. 3).

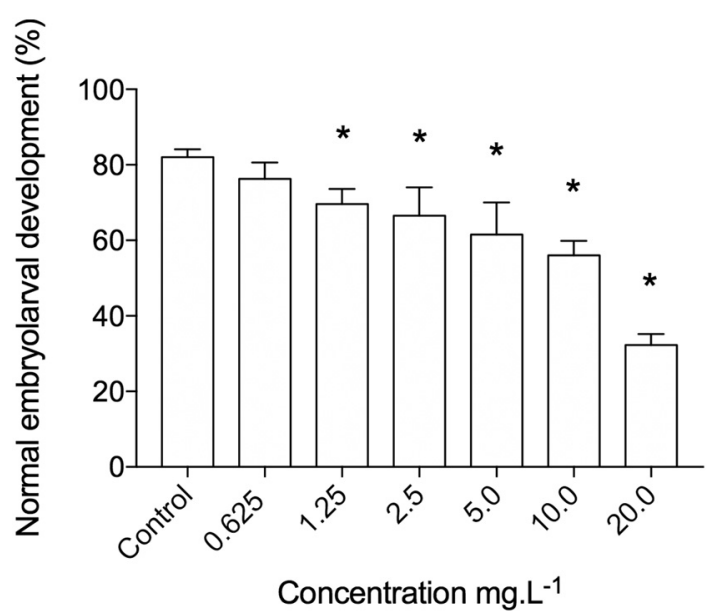

Fig. 2. Embryo-larval development assay. Embryos were exposed for $48 \mathrm{~h}$ to crack cocaine. Asterisks $(*)$ indicate significant differences at $\mathrm{p}<0.05$. 
Table 2

Analysis of the acute and chronic toxicity tests performed on mussels Perna perna exposed to crack cocaine concentrations ( $\mathrm{mg} \cdot \mathrm{L}^{-1}$ ).

\begin{tabular}{llll}
\hline Responses & IC $_{50}$ & NOEC & LOEC \\
\hline Inhibited fertilization $(1 \mathrm{~h})$ & 23.53 & 10.0 & 20.0 \\
Abnormal embryo-larval development $(48 \mathrm{~h})$ & 16.31 & 0.625 & 1.25 \\
\hline
\end{tabular}

Table 3

Analysis of cocaine concentration in the biomarker assay.

\begin{tabular}{ll}
\hline $\begin{array}{l}\text { Nominal concentration of crack cocaine } \\
\left(\mu \mathrm{g} \cdot \mathrm{L}^{-1}\right)\end{array}$ & $\begin{array}{l}\text { Measured concentration of cocaine } \\
\left(\mu \mathrm{g} \cdot \mathrm{L}^{-1}\right)\end{array}$ \\
\hline 0.5 & 0.202 \\
5 & 2.02 \\
50 & 20.2 \\
500 & 202.0 \\
\hline
\end{tabular}

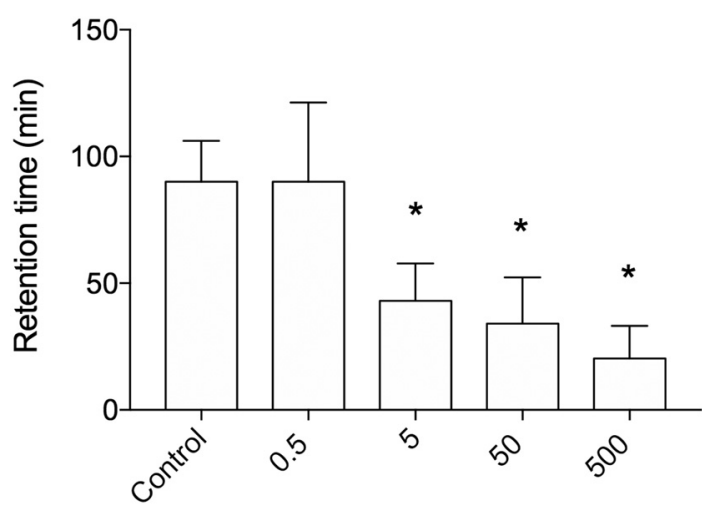

Concentration $\mu \mathrm{g} . \mathrm{L}^{-1}$

Fig. 3. Lysosomal membrane stability (LMS) assessed through Neutral Red retention time (NRRT) assay in haemocytes of mussels $P$. perna. Individuals were exposed for $48 \mathrm{~h}$ to crack cocaine. Asterisks $(*)$ indicate significant differences at $\mathrm{p}<0.05$.

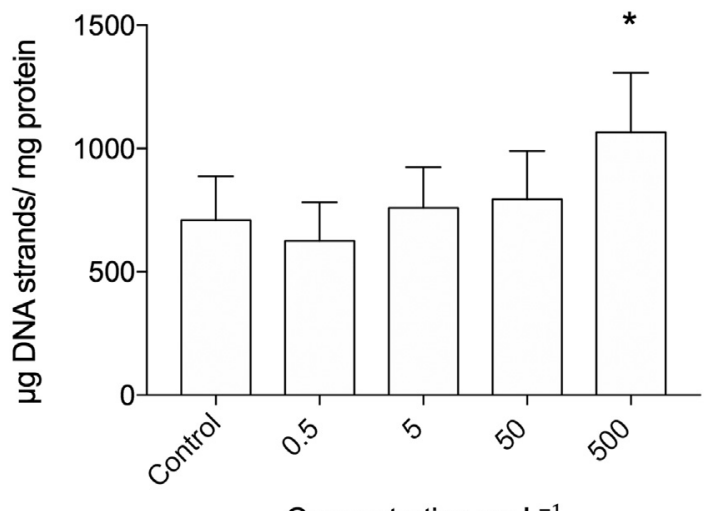

Concentration $\mu \mathrm{g} \cdot \mathrm{L}^{-1}$

Fig. 4. DNA damage (strand breaks) determined in P. perna exposed for $48 \mathrm{~h}$ to crack cocaine. Asterisks $\left({ }^{*}\right)$ indicate significant differences at $\mathrm{p}<0.05$.

Genotoxicity (DNA strand break) was significantly increased in mussels exposed to $500 \mu \mathrm{g} \cdot \mathrm{L}^{-1}$ of crack cocaine ( $\mathrm{p}<0.05$ ) (Fig. 4).

Drugs are designed for a specific and targeted biochemical effect (Singh et al., 2006). Specific modes of action are well known on mammalian biological models, which do not necessarily address the same dose-response in non-target organisms (Daughton, 2001). Data on the environmental hazards associated with these compounds are emerging, but are still scarce (Maranho and Pereira, 2017).

Our study analyzed the effects of crack cocaine in a non-target marine organism after a short-time exposure $(48 \mathrm{~h})$. Toxicity for $P$. perna embryos occurred for concentrations in the order of $\mathrm{mg} \cdot \mathrm{L}^{-1}$, which was not yet reported in aquatic environments. Cytotoxicity was assessed through lysosomal membrane stability. Adopting the criteria previously reported for mussels $P$. perna (Pereira et al., 2011) and clams $R$. philippinarum (Aguirre-Martínez et al., 2013), the threshold values used in this study were as follows: mussels were considered healthy if NRRT was $\geq 80 \mathrm{~min}$, stressed but compensated if NRRT was between $80 \mathrm{~min}$ and $45 \mathrm{~min}$, and in a stressed status if NRRT was $<45 \mathrm{~min}$. Crack cocaine was able to produce significant effects after exposure to $5 \mu \mathrm{g} \cdot \mathrm{L}^{-1}$. Similar results were found by Binelli et al. (2012) for $D$. polymorpha exposed to cocaine concentrations up to $220 \mathrm{ng} \cdot \mathrm{L}^{-1}$. Parolini et al. (2013) also showed that $96 \mathrm{~h}$ of exposure to $1 \mu \mathrm{g} \cdot \mathrm{L}^{-1}$ of benzoylecgonine (the main human metabolite of cocaine) affected the lysosome membrane stability of $D$. polymorpha haemocytes.

The genotoxic action of crack cocaine was observed by a significant increase in DNA strand breaks of digestive glands in mussels exposed to $500 \mu \mathrm{g} \cdot \mathrm{L}^{-1}$. Binelli et al. (2012) observed primary damage to the DNA and chromosomal aberrations in zebra mussel haemocytes exposed to cocaine for a short period of time.

Cyto-genotoxic effects of cocaine and metabolites have been related to oxidative stress in mussels (Binelli et al., 2012; Parolini et al., 2013; Parolini et al., 2015), Wistar rats (Moretti et al., 2016) and humans (Freitas et al., 2014). Cocaine decreased the stability of lysosomal membranes in mussels $D$. polymorpha exposed to $40 \mathrm{ng} \cdot \mathrm{L}^{-1}, 220 \mathrm{ng} \cdot \mathrm{L}^{-1}$ and $10 \mu \mathrm{g} \cdot \mathrm{L}^{-1}$ which may highlights its cytotoxicity and the possible implications of oxidative stress for genotoxic effects (Binelli et al., 2012). Oxidative stress could play a role in liver carcinogenesis process, similar to that exerted by peroxisome proliferators (Rao and Reddy, 1991). The interaction of reactive oxygen species with the bases of the DNA strand, as guanine, leads to the formation of 8-hydroxyguanine (8OHGua) or its nucleoside form deoxyguanosine (8-hydroxy-2'-deoxyguanosine), generating radical adducts and synthesis of 8-hydroxy-2'deoxyguanosine (8-OHdG), one of the most important marker for measuring endogenous oxidative damage to DNA (Valavanidis et al., 2009). Moretti et al. (2016) found that crack cocaine was able to induce genetic damage in peripheral blood and liver cells of rats after acute exposure, whereas Freitas et al. (2014) demonstrated that crack cocaine is able to induce genetic damage in human blood cells.

Our results showed adverse effects (cyto-genotoxicity) in the order of $5 \mu \mathrm{g} \cdot \mathrm{L}^{-1}$ to $500 \mu \mathrm{g} \cdot \mathrm{L}^{-1}$ of crack cocaine or $2.02 \mu \mathrm{g} \cdot \mathrm{L}^{-1}$ to $202.0 \mu \mathrm{g} \cdot \mathrm{L}^{-1}$ of cocaine, suggesting risks to marine environments, since $0.537 \mu \mathrm{g} \cdot \mathrm{L}^{-1}$ of cocaine was found in surface seawater from Santos Bay (Pereira et al., 2016).

Current findings on environmental toxicity of illicit drugs pointing out the need of an efficient and proper treatment of bioactive compounds before wastewater discharges in freshwater and marine environments (Maranho and Pereira, 2017). Crack cocaine toxicity and deleterious effects in marine biota highlights the need to monitor regularly the contamination of coastal waters by illicit drugs. Further marine ecotoxicological studies are necessary to assess bioaccumulation and chronic toxicity of these contaminants of emerging concern in coastal ecosystems.

\section{Acknowledgements}

Pereira C.D.S. thanks São Paulo Research Foundation (FAPESP) for financing the project entitled "Estudo ecotoxicológico e avaliação do risco ambiental de drogas ilícitas em ecossistemas marinhos" (Project \#2015/17329-0). Maranho L.A. thanks CNPq for post-doctoral fellowship (Project no 402931/2015-7). Pereira C.D.S., Abessa D.M.S. and Ribeiro D.A. thank CNPq for productivity fellowships.

\section{References}

Abessa, D.M.S., Carr, R.S., Rachid, B.R.F., Sousa, E.C.P.M., Hortelani, M.A., Sarkis, J.E., 2005. Influence of a Brazilian sewage outfall on the toxicity and contamination of 
adjacent sediments. Mar. Pollut. Bull. 50, 875-885.

Aguirre-Martínez, G.V., Buratti, S., Fabbri, E., DelValls, A.T., Martín-Díaz, M.L., 2013. Using lysosomal membrane stability of haemocytes in Ruditapes philippinarumas a biomarker of cellular stress to assess contamination by caffeine, ibuprofen, carbamazepine and novobiocin. J. Environ. Sci. 25 (7), 1408-1418.

ASTM - American Society of Testing and Materials. E724-89, 1992. Standard guide for conducting static toxicity tests starting with embryos of four species of saltwater bivalve mollusks. In: Annual Book of ASTM Standards: Water and Environmental Technology. vol. 11. pp. 377-394 (Philadelphia).

Baker, D.R., Kasprzyk-Hordern, B., 2013. Spatial and temporal occurrence of pharmaceuticals and illicit drugs in the aqueous environment and during wastewater treatment: new developments. Sci. Total Environ. 454-455, 442-456.

Baker, D.R., Očenášková, V., Kvicalova, M., Kasprzyk-Hordern, B., 2012. Drugs of abuse in wastewater and suspended particulate matter - further developments in sewage epidemiology. Environ. Int. 48, 28-38.

Binelli, A., Pedriali, A., Riva, C., Parolini, M., 2012. Illicit drugs as new environmental pollutants: cytogenotoxic effects of cocaine on the biological model Dreissena polymorpha. Chemosphere 86 (9), 906-911.

Bradford, M.B., 1976. A rapid and sensitive method for the quantification of microgram quantities of protein utilizing the principle of protein-dye binding. Anal. Biochem. 72, 248-254.

Cajaraville, M.P., Bebianno, M.J., Porte, C., Sarasquete, C., Viarengo, A., 2000. The use of biomarkers to assess the impact of pollution in coastal environments of the Iberian Peninsula: a practical approach. Sci. Total Environ. 247, 295-311.

Castiglioni, S., Zuccato, E., Fanelli, R., 2011. Illicit Drugs in the Environment: Occurrence, Analysis, and Fate Using Mass Spectrometry. Wiley-Blackwell, Oxford.

CETESB, 2016. Relatório de qualidade das praias no estado de São Paulo. Available at: http://praias.cetesb.sp.gov.br/wp-content/uploads/sites/26/2013/11/relatoriopraias-2016.pdf.

Cortez, F.S., Pereira, C.D.S., Santos, A.R., Cesar, A., Choueri, R.B., Martini, G.D.A., Bohrer-Morel, M.B., 2012. Biological effects of environmentally relevant concentrations of the pharmaceutical Triclosan in the marine mussel Perna perna (Linnaeus, 1758). Environ. Pollut. 168, 145-150.

Dailianis, S., Domouhtsidou, G.P., Raftopoulou, E., Kaloyianni, M., Dimitriadis, V.K., 2003. Evaluation of neutral red retention assay, micronucleus test, acetylcholinesterase activity and a signal transduction molecule (cAMP) in tissues of Mytilus galloprovincialis (L.), in pollution monitoring. Mar. Environ. Res. 56, 443-470.

Daughton, C.G., 2001. Pharmaceuticals in the environment: overarching issues and overview. In: Daughton, C.G., Jones-Lepp, T. (Eds.), Pharmaceuticals and Personal Care Products in the Environment: Scientific and Regulatory Issues. Symposium Series 791 American Chemical Society, Washington, D.C., pp. 2-38.

Falck, R.S., Wang, J., Carlson, R.G., 2008. Among long-term crack smokers, who avoids and who succumbs to cocaine addiction? Drug Alcohol Depend. 98 (1-2), 24-29.

Freitas, T.A., Palazzo, R.P., de Andrade, F.M., Reichert, C.L., Pechansky, F., Kessler, F., de Farias, C.B., de Andrade, G.G., Leistner-Segal, S., Maluf, S.W., 2014. Genomic instability in human lymphocytes from male users of crack cocaine. Int. J. Environ. Res. Public Health 11 (10), 10003-10015.

Gagné, F., Trottier, S., Blaise, C., Sproull, J., Ernst, B., 1995. Genotoxicity of sediment extracts obtained in the vicinity creosote-treated wharf to rainbow trout hepatocytes. Toxicol. Lett. 78, 175-182.

Hernández, F., Ibáñez, M., Botero-Coy, A.M., Bade, R., Bustos-López, M.C., Rincón, J., Moncayo, A., Bijlsma, L., 2015. LC-QTOF MS screening of more than 1000 licit and illicit drugs and their metabolites in wastewater and surface waters from the area of Bogotá, Colombia. Anal. Bioanal. Chem. 21, 6405-6416.

Johnson, B.A., Ait-Daoud, N., Wang, X.Q., Penberthy, J.K., Javors, M.A., Seneviratne, C., Liu, L., 2013. Topiramate for the treatment of cocaine addiction. JAMA Psychiat. 70 (12), 1338-1346.

Klosterhaus, S.L., Grace, R., Hamilton, M.C., Yee, D., 2013. Method validation and reconnaissance of pharmaceuticals, personal care products, and alkylphenols in surface waters, sediments, and mussels in an urban estuary, Environ. Int. 54, 92-99.

Laranjeira, R., Madruga, C.S., Pinsky, I., Mitsuhiro, S., Caetano, R., 2012. II LENAD Levantamento Nacional de Álcool e Drogas - O uso de maconha, cocaína e crack no Brasil. Available from: http://www.inpad.org.br/images/stories/LENAD/lenad maconhacocaina.pdf.

Lowe, D.M., Fossato, V.U., Depledge, M.H., 1995. Contaminant-induced lysosomal membrane damage in blood cells of mussels Mytilus galloprovincialis from Venice lagoon: an in vitro study. Mar. Ecol. Prog. Ser. 129, 189-196.

Maranho, L.A., Pereira, C.D.S., 2017. Chapter 33. Pharmaceutical and personal care products (ppcps) in the environment: Latin American occurrences, adverse effects and perspectives. In: Araújo, C.V.M., Shinn, C. (Eds.), Ecotoxicology in Latin America. Nova Science Publishers, pp. 537-549.

Maranho, L.A., André, C., DelValls, T.A., Gagné, F., Martín-Díaz, M.L., 2015a. Adverse effects of wastewater discharges in reproduction, energy budget, neuroendocrine and inflammation processes observed in marine clams Ruditapes philippinarum. Estuar. Coast. Shelf Sci. 164, 324-334.
Maranho, L.A., Andre, C., DelValls, T.A., Gagné, F., Martín-Díaz, M.L., 2015b. In situ evaluation of wastewater discharges and the bioavailability of contaminants to marine biota. Sci. Total Environ. 538, 876-887.

Maranho, L.A., DelValls, T.A., Martín-Díaz, M.L., 2015c. Assessing potential risks of wastewater discharges to benthic biota: an integrated approach to biomarker responses in clams (Ruditapes philippinarum) exposed under controlled conditions. Mar. Pollut. Bull. 92 (1-2), 11-24.

Martín-Díaz, M.L., Blasco, J., Sales, D., DelValls, T.A., 2007. Biomarkers study for sediment quality assessment in Spanish ports using the crab Carcinus maenas and the clam Ruditapes philippinarum. Arch. Environ. Contam. Toxicol. 53, 66-76.

Metcalfe, C., Tindale, K., Li, H., Rodayan, A., Yargeau, V., 2010. Illicit drugs in Canadian municipal wastewater and estimates of community drug use. Environ. Pollut. 158 (10), 3179-3185.

Moretti, E.G., Yujra, V.Q., Claudio, S.R., Silva, M.J., Vilegas, W., Pereira, C.D.S., de Oliveira, F., Ribeiro, D.A., 2016. Acute crack cocaine exposure induces genetic damage in multiple organs of rats. Environ. Sci. Pollut. Res. Int. 1-9.

Norber-King, T., 1988. An Interpolation Estimate for Chronic Toxicity: The ICp Approach. National Effluent Toxicity Assessment Center. Technical Reportpp. 05-88.

Olive, P.L., 1988. DNA precipitation assay: a rapid and simple method for detecting DNA damage in mammalian cells. Environ. Mol. Mutagen. 11, 487-495.

Oliveira, M.G.A., Dos Santos, J.N., Cury, P.R., da Silva, V.H., Oliveira, N.R., da Costa, Padovani R., Tucci, A.M., Ribeiro, D.A., 2014. Cytogenetic biomonitoring of oral mucosa cells of crack cocaine users. Environ. Sci. Pollut. Res. Int. 21 (8), 5760-5764.

Parolini, M., Pedriali, A., Riva, C., Binelli, A., 2013. Sub-lethal effects caused by the cocaine metabolite benzoylecgonine to the freshwater mussel Dreissena polymorpha. Sci. Total Environ. 444, 43-50.

Parolini, M., Magni, S., Castiglioni, S., Zuccato, E., Binelli, A., 2015. Realistic mixture of illicit drugs impaired the oxidative status of the zebra mussel (Dreissena polymorpha). Chemosphere 128, 96-102.

Pereira, C.D.S., Abessa, D.M.S., Bainy, A.C.D., Zaroni, L.P., Gasparro, M.R., Bicego, M.C., Taniguchi, S., Furley, T.H., Sousa, E.C.P.M., 2007. Integrated assessment of multilevel biomarker responses and chemical analysis in mussels from São Sebastião, São Paulo, Brazil. Environ. Toxicol. Chem. 26, 462-469.

Pereira, C.D.S., Martín-Díaz, M.L., Zanette, J., Cesar, A., Choueri, R.B., Abessa, D.M.S., Catharino, M.G.M., Vasconcellos, M.B.A., Bainy, A.C.D., Sousa, E.C.P.M., DelValls, T.A., 2011. Integrated biomarker responses as environmental status descriptors of a coastal zone (São Paulo, Brazil). Ecotoxicol. Environ. Saf. 74 (5), 1257-1264.

Pereira, C.D.S., Martín-Díaz, M.L., Catharino, M.G.M., Cesar, A., Choueri, R.B., Taniguchi, S., Abessa, D.M.S., Bícego, M.C., Vasconcellos, M.B.A., Bainy, A.C.D., Sousa, E.C.P.M., DelValls, T.A., 2012. Chronic contamination assessment integrating biomarkers' responses in transplanted mussels: a seasonal monitoring. Environ. Toxicol. 27, 257-267.

Pereira, C.D.S., Abessa, D.M.S., Choueri, R.B., Almagro-Pastor, V., Cesar, A., Maranho, L.A., Martín-Díaz, M.L., Torres, R.J., Gusso-Choueri, P.K., Almeida, J.E., Cortez, F.S., Mozeto, A.A., HLN, Silbiger, ECPM, Sousa, Del Valls, T.A., ACD, Bainy, 2014. Ecological relevance of sentinels' biomarker responses: a multi-level approach. Mar. Environ. Res. 96, 118-126.

Pereira, C.D.S., Maranho, L.A., Cortez, F.S., Pusceddu, F.H., Santos, A.R., Ribeiro, D.A., Cesar, A., Guimarães, L.L., 2016. Occurrence of pharmaceuticals and cocaine in a Brazilian coastal zone. Sci. Total Environ. 548-549, 148-154.

Rao, S.M., Reddy, J.K., 1991. An overview of peroxisome proliferation-induced hepatocarcinogenesis. Environ. Health Perspect. 93, 205-209.

Shihomatsu, H.M., 2015. Development and Validation of Methodology SPE-LC-MS/MS for Pharmaceuticals and Illicit Drug Determination in the Waters of Guarapiranga Dam Sao Paulo/SP, Brazil. (PhD Thesis) University of São Paulohttp://dx.doi.org/10. 11606/T.85.2015.tde-28042015-095207.

Singh, S., Malik, B.K., Sharma, D.K., 2006. Molecular drug targets and structure based drug design: a holistic approach. Bioinformation 1 (8), 314-320.

UNODC (United Nations Office on Drugs and Crime), World Drug Report, 2014. United Nations Publication, Sales No. E.14. XI.7.

UNODC (United Nations Office on Drugs and Crime), World Drug Report, 2017. United Nations Publication, Sales No. E.17.XI.7.

Valavanidis, A., Vlachogianni, T., Fiotakis, C., 2009. 8-Hydroxy-2'-deoxyguanosine (8OHdG): a critical biomarker of oxidative stress and carcinogenesis. J. Environ. Sci. Health C Environ. Carcinog. Ecotoxicol. Rev. 27 (2), 120-139.

Van Nuijs, A.L.N., Pecceu, B., Theunis, L., Dubois, N., Charlier, C., Jorens, P.G., Bervoets, L., Blust, R., Neels, H., Covaci, A., 2009. Spatial and temporal variations in the occurrence of cocaine and benzoylecgonine in waste and surface water from Belgium and removal during wastewater treatment. Water Res. 43 (5), 1341-1349.

Yujra, V.Q., Moretti, E.G., Claudio, S.R., Silva, M.J.D., Oliveira, F., Oshima, C.T.F., Ribeiro, D.A., 2016. Genotoxicity and mutagenicity induced by acute crack cocaine exposure in mice. Drug Chem. Toxicol. 39 (4), 388-391.

Zaroni, L.P., Abessa, D.M.S., Lotufo, G.R., Sousa, E.C.P.M., Pinto, Y.A., 2005. Toxicity testing with embryos of marine mussels: protocol standardization for Perna perna (Linnaeus, 1758). Bull. Environ. Contam. Toxicol. 74, 793-800. 